\title{
Elucidation of the postulates of the germ terrain duality theory with a specific reference to semantics and the distinction between diseased and damaged tissue
}

\section{Proceedings}

When discussing the Germ Terrain Duality theory with people, I encounter a lot of opposition and misunderstanding. Except for a few individuals, most people (whether university graduates or not) seem not to grasp the theory. I can class these people into two camps-both of which suffer from a basic lack of understanding (it would appear) of the English language. The word 'duality' in English means "the state of having two parts or aspects". ${ }^{1}$ Hence the first group of people who say to me-'yes, I long knew harsh labour under the sun caused malaria' and so don't want to take prophylactics (like daraprim) or antimalarials (like artemether) any longer! The second group of people say 'Don't be silly! Plasmodium causes malaria. I've seen the blood slides with plasmodium under the microscope. Don't take us back to the Stone Age' or say things like 'malaria has been eradicated in the USA, yet they play baseball and do hard labour under the sun all the time'. To both groups of people I would refer the editorial 'GermTerrain Duality Of Sickness, Equivalent Of Wave-Particle Duality Of Light For The Biological Sciences?-Bechamp Revisited'.2 After reading that editorial properly they should realize that the GTD theory does not advocate not taking anti malarials. Of course anti malarials cure malaria. What the theory advocates is that malaria has a DUAL causation. Just like water is composed of hydrogen AND oxygen. If a person says water is made up of hydrogen the person is correct, but only PARTLY correct. The same obtains for a person who says water is made up of oxygen. But if a person says water is made up of hydrogen ONLY then that person is outright WRONG. Ditto for the person who says water is made up of oxygen ONLY. The GTD theory states "the etiology of certain diseases/diseased states is better explained as a complex interplay between germs and the inherent anatomical/physiological integrity of the body cells"3 That means BOTH plasmodium AND the inherent cell condition are implicated as the cause of malaria. I do not deny the existence of germs or the dangers they cause. In closing I wish to mention that Professor Bechamp (died 1908) considered himself to be a germ theorist. If Bechamp could be brought back to the present by a time machine he would call himself a germ theorist; not a terrain theorist.

The ONLY difference between Bechamp and Pasteur was their dissimilar theories on HOW and WHY germs did what they did-in other words the MECHANISM. 'Germ theory' meant one thing to Pasteur and another thing to Bechamp. Unfortunately, Pasteur's version of Germ Theory is what the whole world understands as 'Germ Theory' today. The term 'terrain theory' was coined by detractors of Bechamp. If a man does manual labour under the hot sun in the USA (or any other country that has eliminated malaria/plasmodium/ female anopheles mosquitoes) he can NOT and will NOT get malaria; because though his tissues/cells have become DAMAGED by the
Volume 8 Issue 2 - 2019

Seun Ayoade
BSc (Hons) Physiology, university of Ibadan, Nigeria

Correspondence: Seun Ayoade, BSc (Hons) Physiology, university of Ibadan P.O. Box 22325, Oyo state, Nigeria, Email seunoodua@yahoo.com

Received: July 14, 2017 | Published: April 05, 2019

manual labour his tissues have not become DISEASED because there is no plasmodium in his body. If however, in west Africa, a man does manual labour under the hot sun and this man had been bitten by a female anopheles mosquito some time ago and thus has plasmodium ALREADY in him, he will of course firstly suffer tissue DAMAGE too. However, unlike for the American, it will not end there. The plasmodium will begin to FEED and SCAVENGE or FORAGE on those DAMAGED or dead cells/tissues and as a BY PRODUCT of this feeding process, and/or as a CONSEQUENCE of this feeding the man gets malaria. There is thus, in this case of the African a TRANSITION from DAMAGED to DISEASED tissue-ergo the malaria fever. Perhaps one day the postulates of the Germ Terrain Duality Theory will become the new definition for the germ theory or perhaps the Germ Terrain Duality Theory will remain a theory in its own right-time will tell. The keyword however remains DUALITY-a combination of two things. If germs alone caused sickness we must ask why we are not always sick, bearing in mind every single person on this earth has several thousands-if not millions of microbes in their mouths alone at any given time!!

\section{Acknowledgments}

None.

\section{Conflicts of interest}

The author declares there are no conflicts of interest.

\section{References}

1. Oxford Advanced Learners Dictionary. 9th ed. 2015. 475 p.

2. Ameed Raoof. It is not the strongest species that survive, nor the most intelligent, but the most responsive to change: Charles Darwin. Int J Anat Var. 2017;10(1):11-12.

3. Cheng Y, Yu D, Ning G, et al. Clinical, Genetic and Magnetic Resonance Findings in an Infant Affected by Propionic Acidemia. Journal of Molecular and Genetic medicine. 2017;11(2):1747-1862. 